\title{
Simulation of school business process
}

\author{
Usman Jeylani ${ }^{1 *}$, M. Falihul Isbah ${ }^{1}$, Muhammad Ainul Yaqin ${ }^{1}$, Pinkan Veri Diana E. ${ }^{1}$ \\ ${ }^{1}$ Department of Informatics Engineering, Faculty of Science and Technology, Universitas Islam Negeri Maulana Malik Ibrahim, Malang, \\ Indonesia \\ *E-mail: usmanjeylani@gmail.com \\ * corresponding author
}

ABSTRACT

ARTICLE INFO

School is an institution where people learn reading, writing, and learning to have good character. The school has a social interaction system in an organizational relationship. Every institution must have a business process to achieve its vision and mission. The business process has activities carried out to provide services or products. This study analyzes business process systems in schools by designing school business process simulation scenarios and then implementing the design of AnyLogic Software and it can contribute to optimizing the management of business processes within schools, where processes are more structured and systematic. The method used in this study is the Business Process Improvement (BPI) Method to eliminate errors and provide competitive benefits by improving business processes. In applying the BPI method, the results obtained are recommendations for improving school business processes: (1) Adding Buses to schools, (2) Adding School Cooperative Staff to transport goods, and (3) Adding Cashiers in School Cooperatives.

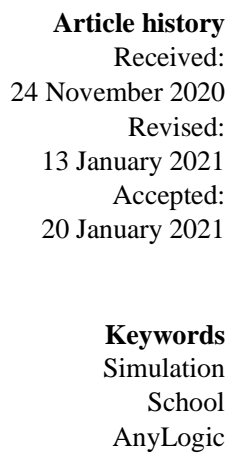

This is an open-access article under the CC-BY-SA license

\section{Introduction}

School is an institution or a place for learning such as reading, writing, and learning to have good characters. Schools are also an integral part of a society that is dealing with the real conditions that exist in society today. School is also a second environment where children practice and grow their personalities [1].

The school has a social interaction system of an entire organization consisting of personal interactions linked together in an organizational relationship. Every institution must have a business process carried out to achieve the specified vision and mission. The business process has activities to provide services or products. A business process is a structured work that is interrelated to solve certain problems. The business process generally involves mapping processes, sub-processes to the activity or activity level. According to Pall [2], the definition of a business process is organizing 
Journal of Engineering and Applied Technology

Vol. 1, No. 2, August 2020, pp. 66-73

human resources. Arbi in [1] explained that materials, energy, equipment, and procedures of work activities are designed to produce a specified final result product.

Every business process is formed by one organization, but it can interact with business processes in other organizations. A business process includes a series of activities starting from a survey of the business process and the organizational and technical environment. Business process simulation provides a structured and interrelated design of a job or activity to solve a problem in a business process. Simulation in business processes is used to assess the dynamic behavior of a process over time, namely the development of the process and the performance of resources in reaction to changes or fluctuations in the environment or certain system parameters.

Based on a relevant study from Helmi [3] on Business Process Analysis and Modeling Using Business Process Improvement (BPI) at the Tutoring Institution (Case Study: Prisma Tutoring Institute), the prism guidance institution is one of currently growing tutoring agencies, however, in carrying out its business processes, there is no clear and standard business process. The main objective of this study is to model and simulate business processes in the Prism tutoring agency using BPMN.

The study was started with a literature study and data collection through interviews, then business process modeling and simulation was conducted using the BPI approach. Modeling and simulation of the proposed business processes and comparison of the results of the process simulation were carried out. The results obtained are the modeling of four business processes that will be improved, the proposed business process model uses the BPI technique and the results of the comparison of current business process simulations.

This study aims to analyze the business process system in schools by designing a school business process simulation scenario then implementing a business process simulation design to contribute to optimizing business process management in schools, where the process is more structured and systematic.

\section{Method}

In this study, the Business process improvement (BPI) method was used to eliminate errors and provide a competitive advantage by improving business processes. Organizing for improvement aims to manage internal and external business processes to become better in an organization.

(1) Understanding the Process is a phase for understanding and exploring all dimensions of today's business processes

(2) Streamlining (Process Simplification) is a phase to improve or increase the effectiveness, efficiency, and adaptability of business processes.

(3) Measurements and control of business processes are carried out to control the course of business processes by checking and measuring the predicted targets to be achieved.

(4) Continuous Improvement is carried out to achieve the implementation of the next improvement process with various processes such as changing, deleting, adding processes. 
Journal of Engineering and Applied Technology

Vol. 1, No. 2, August 2020, pp. 66-73

\section{Results and Discussion}

\subsection{School Business Process Analysis}

The following is the flow of the business process for teachers and students' activities in schools:

(1) Students and teachers go to school

(2) Students put bags in the class and the teachers go to the office

(3) Students and teachers gather in the field to perform ceremonies

(4) Students return to the class

(5) The teacher returns to the office to prepare teaching and learning activities

(6) The teacher goes to the class to teach

(7) Starting teaching and learning activities

(8) Rest break

(9) Students go to school's cooperative, canteen, or play area

(10) The teachers return to the office

(11) Students return to the class

(12) The teachers return to the class to teach

(13) Teaching and learning process

(14) Prayer, Meal, and Rest Break

(15) Entering the class to continue teaching and learning

(16) Teaching and learning process

(17) Going home from school

\subsection{Business Process Flow in Schools' Cooperatives}

(1) Trucks arrive to deliver goods

(2) Workers come to collect goods

(3) Workers put things on shelves

(4) Trucks leave the school' cooperative

\subsection{Analysis of Problems in Business Processes}

In making business process simulations in schools, some problems occur in business processes as presented in Table 1.

Table 1. Business process problems in schools

\begin{tabular}{cll}
\hline No & \multicolumn{1}{c}{ Problem } & \multicolumn{1}{c}{ Business Process in School } \\
\hline 1 & Cooperative employees transport goods & $\begin{array}{l}\text { They are demanded to be fast because there are } \\
\text { more customers to be served }\end{array}$ \\
2 & Cooperative cashier & Number of queues waiting \\
3 & Arrival time of students at school & Students who live far from school come late \\
\hline
\end{tabular}


Journal of Engineering and Applied Technology

Vol. 1, No. 2, August 2020, pp. 66-73

\subsection{Results and Implementation in Any logic}

Business process improvement recommendations are presented in Table 2.

Table 2. Business process improvement recommendations

\begin{tabular}{|c|c|c|c|}
\hline \multirow[t]{2}{*}{ No } & \multicolumn{3}{|c|}{ Business Process in School } \\
\hline & Problem & Improvement Technique & Information \\
\hline 1 & $\begin{array}{l}\text { Cooperative employees } \\
\text { transport goods }\end{array}$ & $\begin{array}{l}\text { Adding cooperative employees } \\
\text { to transport goods }\end{array}$ & $\begin{array}{l}\text { The process of transporting } \\
\text { goods is getting faster }\end{array}$ \\
\hline 2 & Cooperative cashier & Adding cooperative cashier & $\begin{array}{c}\text { The payment process is getting } \\
\text { faster }\end{array}$ \\
\hline 3 & $\begin{array}{c}\text { Arrival time of students } \\
\text { at school }\end{array}$ & Addition of school buses & Reduce delays and worries \\
\hline
\end{tabular}

\subsection{Results and Implementation in Any logic}

The following is the application of a school business process simulation on Analogic:

(1) Students go to school by bus

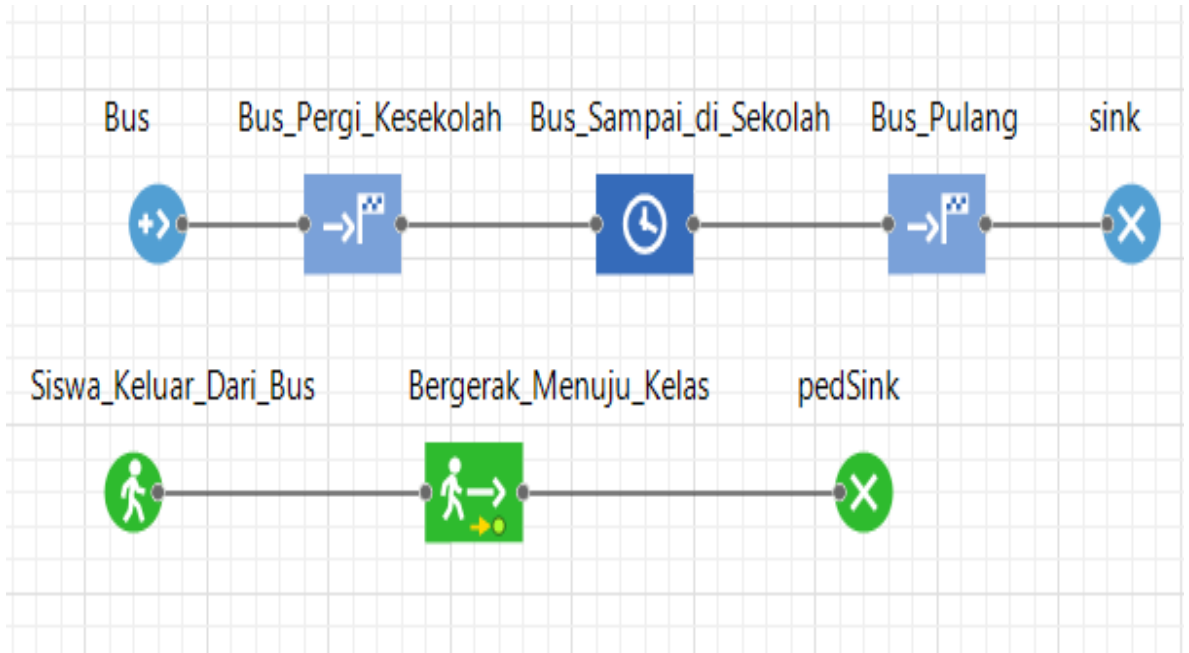

Fig. 1. The process of the bus going to school

Information:

1. Bus (Bus Input)

2. Bus_Pergi_Kesekolah (The process of the bus to the school)

3. Bus_Sampai_di_Sekolah (The bus arrives at the school)

4. Bus_Pulang (The bus leaves the school)

5. Siswa_Keluar_Dari_Bus (The process of students getting off the bus)

6. Bergerak_Menuju_Kelas (Students go to the class)

7. Finish 
Journal of Engineering and Applied Technology

Vol. 1, No. 2, August 2020, pp. 66-73

(2) Students and Teachers' activities

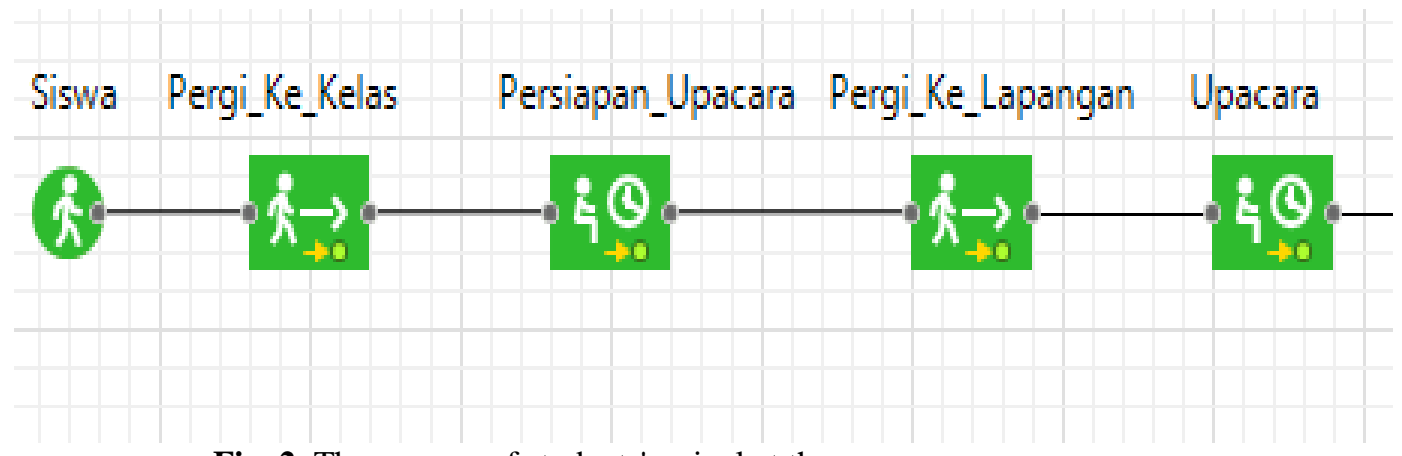

Fig. 2. The process of students' arrival at the ceremony

Information:

1. Siswa (Students arrive at school)

2.Pergi_Ke_Kelas (Students go to the class)

3. Persiapan_Upacara (Students wait for the implementation of the flag ceremony)

4. Pergi_ke_Lapangan (Students go to the field)

5. Upacara (Students carry out the flag ceremony in the field)

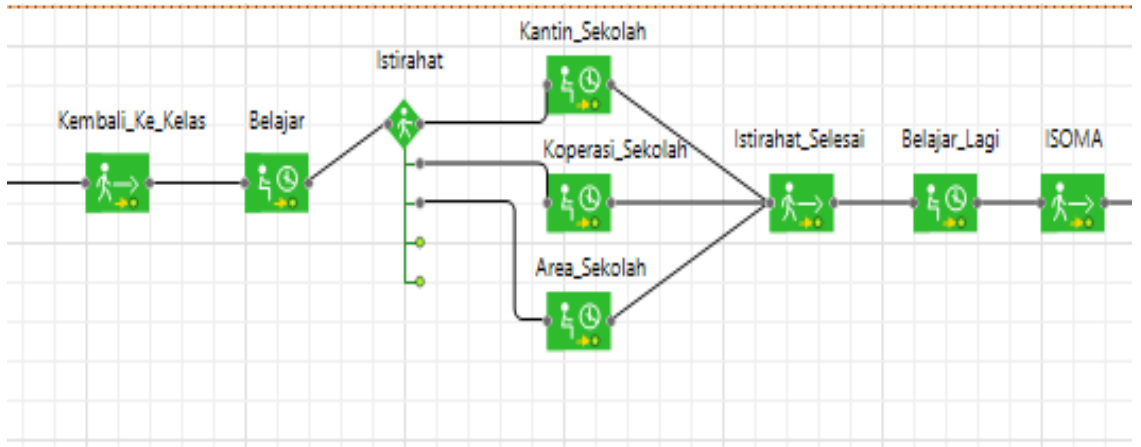

Fig.3. The process of activities after the ceremony to the break (prayer, meal, rest break)

Information:

1. Kembali_Ke_Kelas (Students return to the class)

2. Belajar (Students carry out learning activities in the class)

3. Istirahat (The students choose to the school canteen, the school's cooperative or other school's area)

4. Kantin_Sekolah (Students rest in the canteen)

5. Koperasi_Sekolah (Students buy necessities from the cooperative)

6. Area_Sekolah (Students rest around the school area)

7. Istirahat_Selesai (Students return to the class)

8. Belajar_Lagi (Students carry out teaching and learning activities)

9. ISOMA (Prayer, Meal, Rest Break) 
Journal of Engineering and Applied Technology

Vol. 1, No. 2, August 2020, pp. 66-73

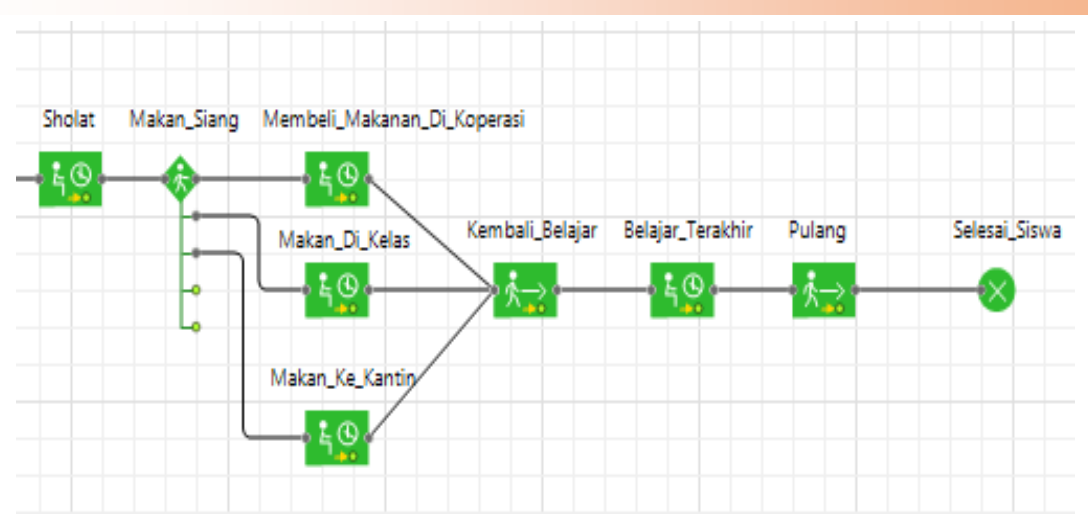

Fig. 4. The process from the break to returning home from school

Information:

1. Sholat (Students go to the prayer room)

2. Makan_Siang (Students take meal rest)

3. Membeli_Beli_Makanan_Di_Koperasi (Students buy food at the school's cooperative)

4. Makan_Di_Kelas (Students have lunch in the class)

5. Makan_Ke_Kantin (Students buy food at the school canteen)

6. Kembali_Belajar (Students return to the class for teaching and learning activities)

7. Belajar_Terakhir (Students end teaching and learning activities)

8. Pulang (students leave school)

9. Selesai_Siswa (Finish)

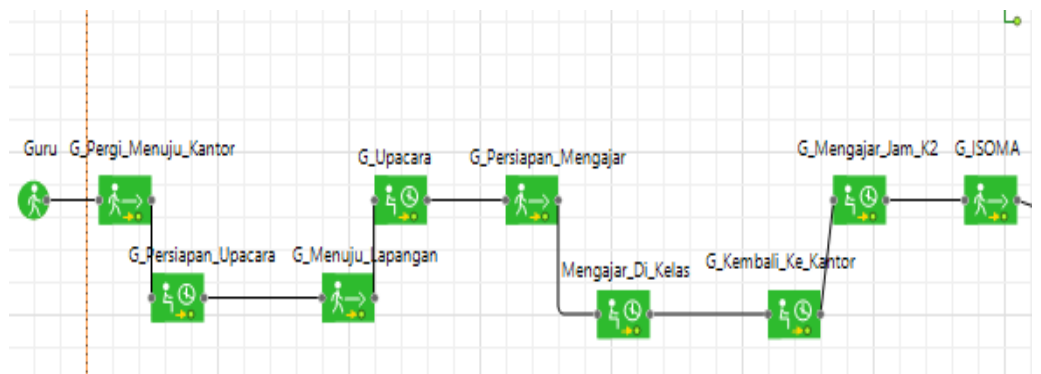

Fig. 5. The process from teacher's arrival to the school break

Information:

1. Guru (The arrival of the teachers at the school)

2. G_Pergi_Menuju_Kantor (Teachers go to the office)

3. G_Persiapan_Upacara (Teachers in the office prepares for the flag ceremony)

4. G_Upacara (Teachers perform the flag ceremony)

5. G_Persiap_Mengajar (Teachers prepare for teaching)

6. Mengajar_Di_Kelas (Teachers carry out teaching activities)

7. G_K Kembali_Ke_Kantor (Teachers return to the office after teaching)

8. G_Mengajar_Jam_K2 (Teachers returns to the class to carry out teaching activities)

9. G_ISOMA (Teachers carry out Prayer, Meal and Rest Break with students) 
Journal of Engineering and Applied Technology

Vol. 1, No. 2, August 2020, pp. 66-73

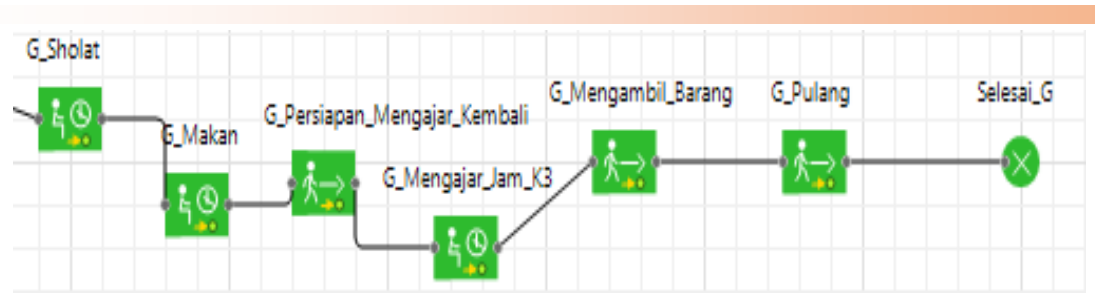

Fig 6. The process for Prayer, Meal, and Rest Break to going home

Information:

1. G_ Sholat (Teachers pray)

2. G_Makan_Ke_Kantin (Teachers have lunch)

3. G_Persiapam_Mengajar_Kembali (Teachers prepare learning activities)

4. G_Mengajar_Jam_K3 (Teachers carry out teaching activities)

5. G_Mengambil_Barang (Teachers returns to the office)

6. G_ Pulang (Teachers leave the school)

7. Selesai_G (Finish)

(3) Business Process in Cooperatives

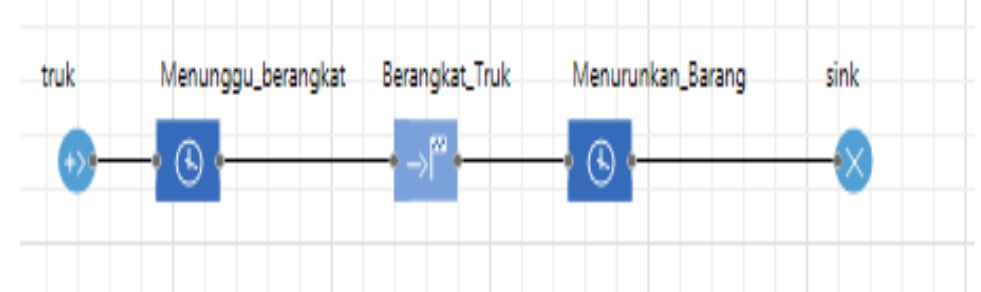

Fig. 7. Arrival process of the delivery truck

Information :

(1) Truk (Trucks transport goods to be sent to the school's cooperative)

(2) Menunggu_berangkat (Waiting for the goods to be transported)

(3) Berangkat_Truk (The trucks depart to send goods)

(4) Menurunkan_Barang (Drop the goods to the school's cooperative)

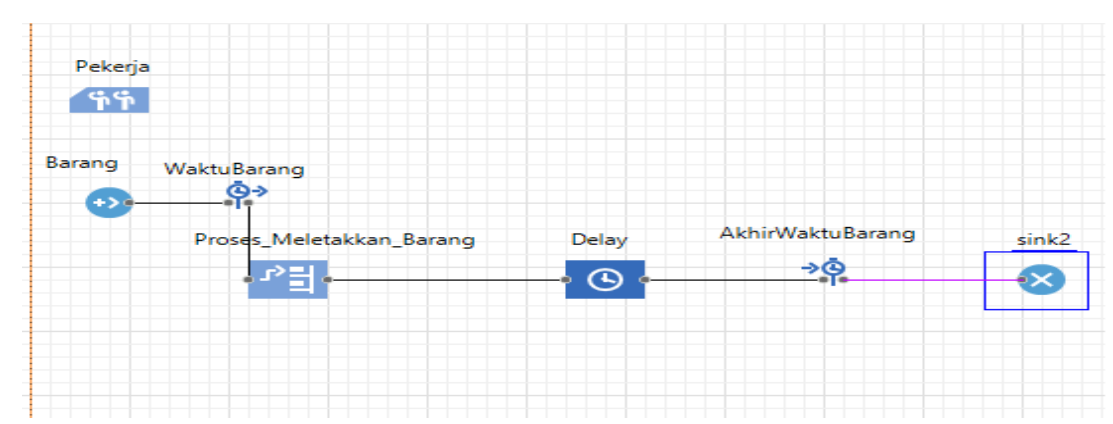

Fig. 8. The process of transporting goods to display racks

Information :

1. Pekerja (The process of inputting the number of workers) 
Journal of Engineering and Applied Technology

Vol. 1, No. 2, August 2020, pp. 66-73

2. Barang (The initial appearance of goods)

3. Waktu Barang (Time of goods data processing)

4. Proses_Meletakan_Barang (The process of workers transporting goods to the display racks)

5. Delay (The process of waiting for goods until students come to pick up goods)

6. AkhirWaktuBarang (Time of data processing ends)

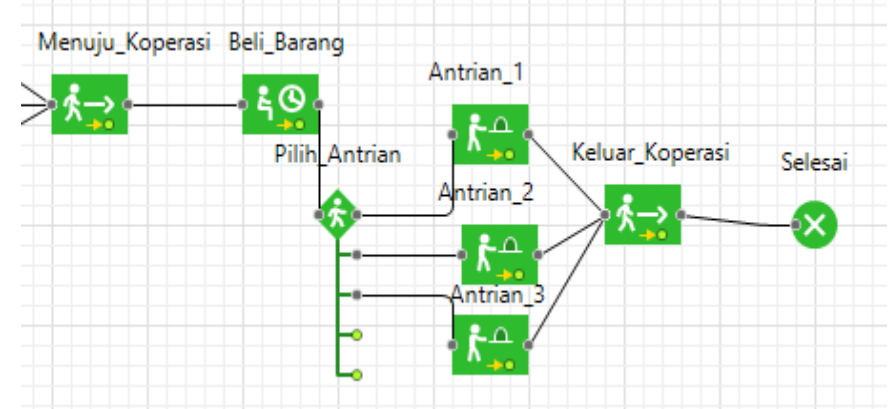

Fig. 9. The process of students buying goods at the cooperative

Information :

1. Menuju_Koperasi (Students go to the school's cooperatives)

2. Beli_Barang (Students buy goods)

3. Pilih_Antrian (Students choose where to queue for payments)

4. Antrian_1 (Process of Students Queuing at the Cashier 1)

5. Antrian _2 (Process of Students Queuing at the Cashier 2)

6. Antrian_3, Process of Students Queuing at the Cashier 3)

7. Keluar_Koperasi, (The students leaves the school's cooperative)

\section{Conclusion}

Based on the results of the discussion in this study, the following conclusions can be drawn. Implementation of school business process simulation can be used to analyze problems that occur and solutions to improve business processes in schools use the BPI (Business process improvement) method. Most problems are caused by inefficient time so that it can hinder the business process. In the implementation of the school business process simulation using Anylogic software, there are shortcomings where the use of time is limited, namely the Pedestrian Library Tool in Anylogic limits the Run Simulation process to only 1 minute.

\section{References}

[1] M. Pidarta, Landasan Kependidikan : Stimulus Ilmu Pendidikan Bercorak Indonesia /Made Pidarta. Jakarta: Rineka Cipta, 1997.

[2] G. A. Pall, Quality Press Management. New Jersey: Prentice-Hall, 1987.

[3] A. T. Helmi, "Analisis dan Pemodelan Proses Bisnis Menggunakan Business Process Improvement (BPI) Pada Lembaga Bimbingan Belajar (Studi Kasus: Lembaga Bimbingan Belajar Prisma)," Universitas Brawijaya, 2018. 